\title{
Accounting treatment of joint operations in Brazil in light of the current accounting standards
}

\author{
Raquel Wille Sarquis ${ }^{1}$ \\ (D) https://orcid.org/0000-0002-9267-9588 \\ Email: raquel.sarquis@usp.br \\ Ariovaldo dos Santos ${ }^{1}$ \\ (D) https://orcid.org/0000-0003-0388-6284 \\ Email: arisanto@usp.br \\ ${ }^{1}$ Universidade de São Paulo, Faculdade de Economia, Administração e Contabilidade, Departamento de Contabilidade e Atuária, São Paulo, SP, \\ Brazil
}

Received on 09.06.2020 - Desk acceptance on 10.16.2020 - $2^{\text {nd }}$ version approved on 06.01.2021

Editor-in-Chief: Fábio Frezatti

Associated Editor: Eliseu Martins

\begin{abstract}
The aim of this paper was to analyze the accounting treatment used by companies in Brazil that have investments in joint operations, in light of the Brazilian and international accounting standards. There are no doubts about the accounting treatment to be used in consolidated statements, but a divergence was identified between the international and Brazilian standards in relation to individual statements. IFRS 11 determines that investors recognize the values of a joint operation proportionally in consolidated and separate statements. However, the Brazilian standard includes a paragraph determining that only joint operations with no legal personality can be measured in individual statements proportionally. CPC 19 foresees different accounting treatments depending on the legal form of the joint operation, omitting the accounting treatment to be used in joint operations with a separate vehicle. The topic of joint operations is relevant, as the accounting treatment used in Brazil can mean our accounting practices do not comply with the international ones. Besides contributing to the literature on joint businesses, this essay indicates to regulatory bodies the need to modify the Brazilian standard so that it fits the international ones. As well as discussing the current standard, an analysis was carried out of companies in Brazil that have joint operations and the respective accounting treatments used to infer how well they fit the international standards. The results indicate that the accounting statements of the companies in Brazil with joint operations, composed through a separate vehicle, do not comply with the international standards. The main contribution of this essay is that it draws the attention of companies, auditors, and regulators to this non-compliance.
\end{abstract}

Keywords: joint operations, individual statements, CPC 19/IFRS 11, non-compliance.

Correspondence address

Raquel Wille Sarquis

Universidade de São Paulo, Faculdade de Economia, Administração e Contabilidade, Departamento de Contabilidade e Atuária

Avenida Professor Luciano Gualberto, 908 - CEP 05508-010

Cidade Universitária - São Paulo - SP - Brasil 


\section{INTRODUCTION}

The adoption of Law n. 11,638/2007 represented a milestone in the process of convergence with the international accounting standards in Brazil, as it determined convergence per se and introduced alterations to Law n. 6,404/1976, which impeded the adoption of various procedures required by the International Financial Reporting Standards (IFRS), issued by the International Accounting Standards Board (IASB). Today there are very few differences between the Brazilian and international standards, and one of these will be addressed in this essay.

Although rare, these differences can mean that accounting statements in Brazil are not in compliance with the international standards and, therefore, they need to be understood by accounting information users. In this sense, Zeff (2012) warns that when companies and auditors state that accounting statements are in compliance with the international accounting standards, they need to make it clear whether, and to what extent, this corresponds to the IFRS issued by the IASB.

It is important to observe that the international standards focus on the economic group (consolidated statements), but the IASB foresees the possibility of elaborating what they call separate statements, which can be equated to what in Brazil we call individual statements. Regarding the obligation to elaborate individual statements, it is important to highlight that Brazil was the first country in the world to adopt the international standards not only in consolidated statements, but also in individual ones.

Because of this there are some difficulties in implementing certain accounting treatments foreseen in the IFRS in our individual accounting statements, which can require specific adaptations. One example of this is precisely the accounting treatment of joint operations, which represent an investment type whose control of the business is shared (and requires unanimous consent) between the parties involved.
The current international standard is IFRS 11 - Joint Arrangements (International Accounting Standards Board, 2011), which determines that investors must recognize in their statements their own share of each one of the assets, liabilities, revenues, and expenses of the joint operation, not only in the consolidated statements, but also in the separate ones. However, when Brazil translated IFRS 11, through Accounting Pronouncements Committee (Comitê de Pronunciamentos Contábeis) CPC 19 (R2), it added a paragraph (27A) establishing that only operations with no legal personality can be accounted for using the approach foreseen in the IFRS.

This additional paragraph is creating inconsistencies. The first of these is that CPC 19 (R2) determines different accounting treatments depending on the legal way in which the joint operation was composed, a differentiation that does not exist in the IFRS and focuses on the legal form alone instead of the economic essence. The second point is that CPC 19 (R2) omits the accounting treatment to be used by companies with joint operations composed through a separate vehicle. Because of this omission, companies are using different treatments from what is foreseen in the IFRS, meaning that their individual statements are not in compliance with the IASB standards.

The aim of this essay is to analyze the accounting treatment used by companies operating in Brazil, with investments in joint operations, in light of the Brazilian and international accounting standards. It is hoped that the analyses and discussions presented here can contribute both to the academic literature on joint arrangements investments and, more specifically, to the literature on joint operations. The other hope is to contribute to regulatory bodies, auditors, and companies with this type of investment, by drawing attention to the consequences of the inclusion of paragraph 27A in CPC 19 (R2) and to the possible non-compliance of the individual statements elaborated in Brazil with the international accounting standards (IFRS).

\section{ACCOUNTING STANDARDS}

\subsection{Concept and Classification of Joint Arrangements}

The international standard that addresses joint arrangements is IFRS 11 - Joint Arrangements, translated through Technical Pronouncement CPC 19 (R2) - Joint Arrangements. Conceptually, a joint arrangement is one in which two or more parties have joint control, with two main characteristics: (i) the integral parties are bound by a contractual agreement and (ii) the contractual agreement 
gives these two or more integral parties joint control of the business (Accounting Pronouncements Committee, 2012, item 5).

Joint control, according to item 7 of CPC 19 (R2), is "the contractually agreed sharing of the control of an arrangement, which exists only when decisions about the relevant activities require unanimous consent of the parties sharing control." In other words, a joint arrangement exists when the parties involved control the business jointly and, therefore, all the relevant decisions about the business activities require those parties' unanimous consent.

CPC 19 (R2) determines that joint arrangements should be classified as (i) joint operations or (ii) joint ventures. This classification must be made based on an analysis of the rights and obligations of the integral parties in the arrangement. If those parties have rights over the assets and present obligations regarding the liabilities, the joint arrangement should be classified as a joint operation. On the other hand, if the analysis indicates that the parties only have rights over the net assets, it should be classified as a joint venture.

To evaluate the rights and obligations of the integral parties of the arrangement, IFRS 11 and CPC 19 (R2) determine a set of factors that must be taken into consideration. The first of these is the existence or not of a separate vehicle. If the joint arrangement does not have its own legal personality, a joint operation is concerned, in which the integral parties will have rights and obligations regarding the assets, liabilities, revenues, and expenses. If it is composed through a separate vehicle, the joint arrangement can be classified both as a joint operation and a joint venture. To make this differentiation, the company should consider the legal form of that separate vehicle.

In the legal form analysis, the company should assess whether that separate vehicle is really independent from the integral parties of the arrangement, that is, whether the assets and liabilities that are kept in that separate vehicle actually belong to the separate vehicle. If they do, the classification is as a joint venture. On the other hand, if it composed by means of a separate vehicle, but the assets and liabilities do not actually belong to that separate vehicle but instead to the integral parties, the joint arrangement is a joint operation. Besides the legal form, the standard determines that the investor should also assess the terms of the agreement.

Thus, a joint operation is a joint arrangement in which the integral parties have rights over the assets and obligations through the liabilities related to the arrangement, independently of the legal way it is composed. That is, joint operations can be composed without their own legal personality or through a separate vehicle.

\subsection{Accounting Treatment}

If joint arrangements are classified as joint ventures, IFRS 11 determines that the equity method (EM) must be obligatorily used, despite there being various papers suggesting that proportional consolidation would result in more relevant accounting information (Bauman, 2007; Graham et al., 2003; Sarquis \& Santos, 2018; Soonawalla, 2006; Stoltzfus \& Epps, 2005).

On the other hand, if the joint arrangement is classified as a joint operation, IFRS 11 determines that the parties involved should recognize in their financial statements their share of the assets, liabilities, revenues, and expenses of the joint operation. Despite the similarity, this procedure for measuring joint operations is different from what would be proportional consolidation, as the rights and obligations in relation to the assets, liabilities, revenues, and expenses of the joint operation, specified in the contractual agreement, may be different from the percentage share in the joint operation.

\section{CPC 19 AND THE ADAPTATION FOR INDIVIDUAL ACCOUNTING STATEMENTS}

As already stated, the international accounting regulation process focuses on financial statements from the economic group and, therefore, the accounting treatment mentioned in the previous topic only focuses on consolidated statements. The Brazilian legislation, however, requires the elaboration and presentation of individual statements. Consequently, when Brazil translated IFRS 11 through CPC 19 (R2), it included a paragraph (27A) with the following guidance: "In their individual accounting statements, only entities with interests in joint operations organized without their own legal personality should apply items 20 to 22 or 23 of this Pronouncement" (Accounting Pronouncements Committee, 2012, p. 5). In other words, CPC 19 (R2) determines that, in individual financial statements, only those investors that have joint operations composed WITHOUT a legal personality should apply the accounting procedure that recognizes in their financial statements the rights and obligations regarding the assets, liabilities, revenues, and expenses of the joint operation. 
The first point to be observed is that CPC 19 (R2) clearly differentiates the accounting treatment of joint operations composed WITHOUT a legal personality from joint operations composed WITH their own legal personality. This differentiation does not exist in the IFRS and it is already an indication of non-compliance with the IASB standards. Moreover, using different accounting treatments due to the existence or not of a separate vehicle, where, in essence, independently of the legal form of constitution, the joint investors have rights and obligations regarding the assets, liabilities, revenues, and expenses of the joint operation, means the Brazilian standard focuses more in the legal form than the economic essence of the operation.

It warrants mentioning that accounting information is only relevant if it adequately reflects the economic essence of operations. Therefore, the prevalence of economic essence over form is one of the IASB's main flagships (Martins et al., 2007) and represents "one of the main roots that feed and sustain the whole accounting tree" (Iudícibus, 2007, p. 11). By addressing the fundamental qualitative characteristics of accounting information, the IASB's Conceptual Framework itself argues that information that only reflects legal form and not economic essence does not faithfully represent the economic phenomenon.

Moreover, item 27A of CPC 19 (R2) also does not specify what the accounting treatment in individual financial statements should be for joint operations composed through a separate vehicle. This omission from CPC 19 (R2) may result in relevant problems for the recognition of this type of investment in the individual statements of companies operating in Brazil, as these companies may use different procedures that are inconsistent with the IFRS.

Despite the international standards not recognizing individual statements, the IASB foresees the disclosure of separate statements, which can be equated with what in Brazil we call individual statements. In this sense, IFRS 11 determines that in separate statements joint operations should be recorded in the same way as in consolidated statements. That is, for the IASB all joint operations (independently of the legal form) should be recognized both in the consolidated and in the separate statement, using the proportional share of assets, liabilities, revenues, and expenses of the joint operation. Thus, the adaptation made in Brazil with the inclusion of item 27A represents an inconsistency between the Brazilian standard and the international one.

In this sense, it is valid to mention the academic literature that suggests that these adaptations, which are made regarding the adoption of the international accounting standards in jurisdictions with different cultural and institutional environments, can result in the emergence of national versions of the IFRS (Kvaal \& Nobes, 2012; Nobes, 2011, 2013). Zeff (2012) also highlights that this is one of the IASB's main challenges.

\section{ANALYSIS OF COMPANIES OPERATING IN BRAZIL}

\subsection{Sample}

To evaluate what accounting treatment companies operating in Brazil have been using to measure their joint operations, an analysis was conducted of the 2019 accounting statements of all publicly-traded non-financial companies that present consolidated accounting statements and that form part of the database kept by the Institute Foundation for Accounting, Actuarial, and Financial Research (Fipecafi). This led to the identification of 147 companies and, after analyzing the accounting statements of these companies, it was verified that 13 have joint operations (Table 1). 
Table 1

Companies used

\begin{tabular}{|c|c|c|c|}
\hline Name of the companies & Sector & $\begin{array}{l}\text { Value added in } 2019 \\
\text { (R\$ thousand) }\end{array}$ & $\begin{array}{l}\text { Volume traded } \\
\text { (quant.) }\end{array}$ \\
\hline Cemig Geração e Transmissão & Energy & $4,094,490$ & 0 \\
\hline Companhia Siderúrgica Nacional (CSN) & Steel and metallurgy & $7,839,357$ & $4,337,253$ \\
\hline Copel Geração e Transmissão & Energy & $3,231,222$ & 199,345 \\
\hline CPFL Geração & Energy & $2,320,329$ & $1,316,602$ \\
\hline Engie Brasil Energia & Energy & $6,201,746$ & $1,662,045$ \\
\hline J. Macêdo & Consumer goods & 500,128 & 0 \\
\hline JSL & Transport & $4,040,346$ & 327,672 \\
\hline M. Dias Branco & Consumer goods & $2,602,310$ & 947,451 \\
\hline Petrobras & Energy & $270,887,000$ & $17,887,836$ \\
\hline Petrobras Distribuidora & Wholesale & $25,470,000$ & $4,490,290$ \\
\hline Suzano Holding & Pulp and paper & $11,433,217$ & 0 \\
\hline Suzano S.A. & Pulp and paper & $11,431,428$ & $4,814,071$ \\
\hline Totvs & Digital industry & $1,684,704$ & $1,497,305$ \\
\hline
\end{tabular}

Source: Elaborated by the authors.

These companies represent the totality of those that have joint operations and that meet the previously specified criteria. Also, the wealth created by these companies represented $4.7 \%$ of Brazilian gross domestic product (GDP) in 2019 and the total volume of their stocks traded represented $10.6 \%$ of the total São Paulo Stock Exchange Index (Ibovespa), highlighting the importance of these companies to the Brazilian market. It is important to remember that joint operations can also be used by privately-held or limited companies, which were not analyzed here due to a lack of information.

\subsection{Analysis of the Accounting Treatment of the Companies in the Sample}

- M. Dias Branco: It has one joint operation, shared with another two investors (33\%). In the main accounting policies note (note 4 ), it mentions that the joint operation has its own legal personality and, therefore, "its assets, its liabilities, its revenues, and expenses are only recognized, in relation to their share, in the consolidated accounting statements [...] the investment is recognized in the individual statements using the equity method."

Thus, M. Dias Branco follows item 27 of CPC 19, which specifies that, in individual financial statements, only joint operations composed WITHOUT a legal personality can be measured by recognizing the proportional assets, liabilities, revenues, and expenses. As CPC 19 omits the accounting treatment of joint operations composed with a separate vehicle, this company "chose" the EM. It is observed, however, that this procedure is not in compliance with what the international standards foresee, as the IASB determines that all joint operations, including in the separate financial statements, should be measured by recognizing proportional values, independently of the legal form.

- Engie Brasil: It maintains joint operations in Itá Energética S.A. - Itasa (composed through a separate vehicle) and in consortia (without a legal personality). The accounting policy note indicates that assets, liabilities, revenues, and expenses, both of the operation in Itasa and of the consortia, are recognized in the consolidated accounting statements proportionally. However, in the individual statements, the company uses different accounting treatments, depending on how the joint operation was composed. Specifically, as the consortia were composed without a legal personality, the company uses the same procedure as the consolidated statements. However, as Itasa was composed though a separate vehicle and CPC 19 omits the accounting treatment to be used in individual statements, Engie chose the EM.

As already mentioned, the use of this accounting treatment can mean that the individual financial statements are not in compliance with the IFRS. Indeed, Engie itself recognizes this in note 2"A", on the preparation basis, by mentioning that 
the individual statements of the controlling company were prepared in compliance with the accounting practices adopted in Brazil, which are convergent with the IFRS standards, except the recording of the joint-controlled operation in Itá Energética S.A. ("Itasa"), which, in accordance with the Brazilian standards, is recognized using the equity method, while following the IFRS, assets, liabilities, and earnings are recognized proportionally to their share in the investment.

- Petrobras: It has two joint operations composed through separate vehicles, as well as various joint operations without a legal personality. In the consolidated statements, it uses the approach of recognizing proportional assets, liabilities, revenues, and expenses, but in the individual statements it specifies in its explanatory note 29.6 that "only joint operations composed through a separate vehicle with its own legal personality are assessed using the EM. For other joint operations, the company recognizes its assets, liabilities, and respective revenues and expenses in these operations." This procedure is in compliance with CPC 19, but not with the international standards.

- Petrobras Distribuidora and J. Macêdo: Both these companies have a single joint operation composed through a separate vehicle. Therefore, both mention in the accounting policies note that in the consolidated statements they recognize their share of the revenues, expenses, assets, and liabilities held in the joint operation, but that in the individual statements they use the EM, as the joint operation was composed through a separate vehicle. Thus, they are in compliance with the procedure foreseen in CPC 19, but not with the IFRS.

- Suzano S.A.: It has investments in a joint operation composed through a separate vehicle (Veracel Celulose S.A.). The accounting policies note (3.2.5) mentions that in the consolidated statements the balances of the assets, liabilities, revenues, and expenses of the joint operation are recognized proportionally. However, regarding the individual statements, it states (note 3.2.1) that "investments in controlled companies, affiliates, and joint ventures are assessed using the equity method (...) investments in joint operations are recognized proportionally in relation to the share in the joint operation."

Thus, this note appears to indicate that Suzano S.A. used the same accounting treatment in the individual and consolidated accounting statements, that is, it recognized assets, liabilities, revenues, and expenses from the joint operation proportionally. This procedure would be discordant with CPC 19, but it would be in compliance with the international standards. Yet, there appears to be a divergence between the accounting treatment disclosed in the accounting policies note and the one actually used by the company, since, from analyzing the composition of the investments account in the balance sheet of the controlling company, it is possible to perceive that the share of Suzano S.A. in the net equity of the joint operation (Veracel Celulose) is included in the balance of the investments account of the controlling company, which suggests that the joint operation was measured using the EM in the individual financial statements.

- Suzano Holding and JSL S.A.: Both have shares in joint operations through controlled companies and, therefore, these operations only appear in the consolidated statements when the assets, liabilities, revenues, and expenses of the joint operations are recognized proportionally to the percentage share.

- Totvs S.A.: It has a joint operation composed through a separate vehicle. In accounting policies note 2.3, the company mentions that "the assets, liabilities, revenues, and expenses related to its interests in a joint operation are recorded individually in the consolidated financial statements." However, it does not provide information about the accounting treatment in the individual statements. Despite this omission, from analyzing the investments note (14), it is possible to perceive that Totvs' share in the joint operation is included in the balance of the investments account in the individual financial statements, which suggests that the joint operation is measured using the EM.

- Companhia Siderúrgica Nacional (CSN): It has two joint operations, one composed through a separate vehicle (Itá Energética) and another without its own legal personality (Igarapava Hydroelectric Power Plant consortium). In the accounting policies note (number 2"B"), CSN mentions that

joint operations are recorded in the financial statements to represent the Company's contractual rights and obligations. Thus, the assets, liabilities, revenues, and expenses related to its interests in a joint operation are individually recorded in the financial statements.

As can be perceived, it is unclear which statements this accounting procedure is used for, whether only in the consolidated one or also in the individual ones. However, from analyzing note 8 , it is possible to perceive that CSN's share in Itá Energética S.A. (separate vehicle) is included in the balance of the investments account of its individual financial statements, which suggests that this joint operation is measured using the EM. On the other 
hand, in the case of the joint operation composed without its own legal personality (Igarapava Hydroelectric Power Plant consortium), there is no balance in the investments account, which appears to indicate that, for this joint operation, CSN uses the same accounting procedure as the consolidated financial statements in the individual financial statements: proportional recognition of assets, liabilities, revenues, and expenses.

- Copel Geração and Transmissão S.A. (Copel GT): It has two consortia classified as joint operations without a legal personality. In relation to the accounting treatment, it states in its note 4.1.5 that "the joint operations are recorded according to the proportional share of assets, liabilities, and earnings, in the company that has the share." Despite not making it clear if this accounting procedure is only used in the consolidated statements or also in the individual ones, as they are two consortia without a legal personality, it is possible to acknowledge that this accounting procedure of recognizing proportional values was used both in the consolidated and individual statements. This evidence is corroborated by the fact that there is no joint operations balance in the investments account, nor in the individual statements and much less in the consolidated ones.

- CPFL Geração de Energia S.A. and Cemig Geração e Transmissão: Neither of them disclosed clear information about the nature of the joint operations, nor about the accounting treatment used in the consolidated and individual financial statements.

\section{SUMMARY AND CONCLUDING REMARKS}

This essay aimed to analyze the accounting treatment used by companies that operate in Brazil and that have investments in joint operations, in light of the Brazilian and international accounting standards. There are no doubts in relation to the accounting treatment to be used in consolidated financial statements. However, there is a divergence between the Brazilian and international standards in relation to the treatment of individual statements. Of the 147 companies analyzed, 13 were identified as having joint operations. Below we present a summary of the analyses:

- Eight companies (M. Dias Branco, Engie, Petrobras, Petrobras Distribuidora, J. Macêdo, Suzano, Totvs, and CSN) mentioned that the treatment used in the individual statements depends on the legal form of the joint operation, where, for joint operations WITHOUT a separate vehicle, the proportional approach to recognizing assets, liabilities, revenues, and expenses is used, while for those carried out through a separate vehicle, the measurement was done using the EM.

- Copel GT has joint operations composed without a separate vehicle and, therefore, the approach was that of recognition proportional to the percentage share in the consolidated and individual statements.

- Suzano Holding and JSL have joint operations through their controlled companies and, therefore, they only appeared in the consolidated statements, using the proportional approach to recognizing assets, liabilities, revenues, and expenses.
- CPFL Geração and Cemig GT did not disclose sufficient information for the assessment.

It is therefore observed that the companies are using, in their individual financial statements, the proportional approach to recognizing assets, liabilities, revenues, and expenses only for joint operations WITHOUT a separate vehicle. However, for joint operations composed through a separate vehicle, as the CPC does not determine which accounting practice should be used, the companies are using the EM, possibly due to the influence of corporate legislation.

This procedure, used in Brazil, is inconsistent with what is foreseen in the international standards, as IFRS 11 determines that all joint operations, independently of the legal form, should be measured using the proportional approach to recognizing assets, liabilities, revenues, and expenses, both in the consolidated and in the separate statements. However, when Brazil translated IFRS 11, through CPC 19, it included a paragraph (27A) determining that, in individual statements, only joint operations composed WITHOUT a separate vehicle can be measured using proportional values recognition, but it does not specify what accounting treatment should be used for joint operations composed through a separate vehicle. Due to this omission from CPC 19 (R2), it was verified that the companies are using the EM, which would contradict the IFRS. Therefore, the inclusion of paragraph $27 \mathrm{~A}$ is meaning that the individual financial statements of companies operating in Brazil are not in compliance with the international standards. 


\section{REFERENCES}

Bauman, M. P. (2007). Proportionate consolidation versus the equity method: additional evidences on the association with bond ratings. International Review of Financial Analysis, 16(5), 496-507. https://doi.org/10.1016/j.irfa.2007.06.005

Comitê de Pronunciamentos Contábeis. (2012). Pronunciamento Técnico CPC 19 (R2) - Negócios em conjunto. Comitê de Pronunciamentos Contábeis. http://static.cpc.aatb.com.br/ Documentos/274_CPC_19_\%20R2_rev\%2013.pdf

Graham, R. C., King, R. D., \& Morrill, C. K. (2003). Decision usefulness of alternative joint venture reporting methods. Accounting Horizons, 17(2), 123-137. https://doi.org/10.2308/ acch.2003.17.2.123

International Accounting Standards Board. (2011). IFRS 11 - Joint Arrangements. IASB - International Accounting Standards Board.

Iudícibus, S. (2007). Ensaio sobre algumas raízes profundas da contabilidade, em apoio aos princípios fundamentais. Revista de Contabilidade e Organizações, 1(1), 8-15. https://doi. org/10.11606/rco.v1i1.34693

Kvaal, E., \& Nobes, C. (2012). IFRS policy changes and the continuation of national patterns of IFRS practice. European Accounting Review, 21(2), 343-371. https://doi.org/10.1080/09 638180.2011 .611236

Law n. 6,404/1976. (1976). Diário Oficial da União. http://www. planalto.gov.br/ccivil_03/leis/16404consol.htm

Law n. 11,638/2007. (2007). Diário Oficial da União. http://www. planalto.gov.br/ccivil_03/_ato2007-2010/2007/lei/111638.htm
Martins, E., Martins, V. A., \& Martins, É. A. (2007). Normatização contábil: ensaio sobre sua evolução e o papel do CPC. Revista de Informação Contábil, 1(1), 7-30. https://doi.org/10.34629/ ufpe-iscal/1982-3967.2007.v1.7-30

Nobes, C. (2011). IFRS practices and the persistence of accounting system classification. Abacus, 47(3), 267-283. https://doi.org/10.1111/j.1467-6281.2011.00341.x

Nobes, C. (2013). The continued survival of international differences under IFRS. Accounting and Business Research, 42(2), 83-111. https://doi.org/10.1080/00014788.2013.770644

Sarquis, R. W., \& Santos, A. (2018). Impactos da eliminação da consolidação proporcional nas demonstrações contábeis da Itaúsa. Revista Contabilidade \& Finanças, 29(77), 213-228. https://doi.org/10.1590/1808-057x201804470

Soonawalla, K. (2006). Accounting for joint ventures and associates in Canada, UK, and US: do US rules hide information? Journal of Business Finance \& Accounting, 33(3-4), 395-417. https://doi.org/10.1111/j.14685957.2006.00609.x

Stoltzfus, R. L., \& Epps, R. W. (2005). An empirical study of the value-relevance of using proportionate consolidation accounting for investments in joint ventures. Accounting Forum, 29(2), 169-190. https://doi.org/10.1016/j. accfor.2004.10.001

Zeff, S. A. (2012). The evolution of the IASC into the IASB and the challenges it faces. The Accounting Review, 87(3), 807-837. https://doi.org/10.2308/accr-10246 